\title{
PENGARUH STRUKTUR MODAL, LIKUIDITAS, DAN KEPUTUSAN INVESTASI TERHADAP NILAI PERUSAHAAN PADA PERUSAHAAN JASA SUB SEKTOR PARIWISATA, HOTEL, DAN RESTORAN YANG TERDAFTAR DI BEI TAHUN 2014-2018
}

\author{
Dr. Mikrad. Drs., MM \\ Agung Budi, MM \\ Fakultas Ekonomi dan Bisnis \\ Universitas Muhammadiyah Tangerang
}

\begin{abstract}
ABSTRAK
Penelitian ini bertujuan untuk mengetahui Pengaruh Struktur Modal, Likuiditas, dan Keputusan Investasi terhadap Nilai Perusahaan pada perusahaan jasa sub sektor pariwisata, hotel, dan restoran yang terdaftar di BEI tahun 20142018. Penelitian ini bersifat kuantitatif. Metode yang digunakan adalah regresi data panel melalui program Eviews 9.0. Hasil penelitian ini menunjukkan bahwa Struktur Modal secara parsial berpengaruh terhadap Nilai Perusahaan, Likuiditas secara parsial tidak berpengaruh terhadap Nilai Perusahaan dan Keputusan Investasi secara parsial berpengaruh terhadap Nilai Perusahaan. Sedangkan secara simultan Struktur Modal, Likuiditas, dan Keputusan Investasi berpengaruh secara bersama-sama terhadap Nilai Perusahaan. Kemampuan variabel independen dalam menjelaskan nilai perusahaan sebesar $32,19 \%$ sebagaimana ditunjukkan dengan besarnya adjusted $R$-squared sebesar 0.321977 sedangkan sisanya $67,81 \%$ dipengaruhi faktor lain yang tidak dimasukkan kedalam penelitian.
\end{abstract}

Kata Kunci: Struktur Modal, Likuiditas, Keputusan Investasi, Nilai Perusahaan

\section{PENDAHULUAN}

\section{A. Latar Belakang Masalah}

Perusahaan jasa adalah
kegiatan

perusahaan yang kegiatan tidak berwujud atau jasa yang memiliki tujuan untuk memperoleh keuntungan atau laba. Para investor kini mulai tertarik berinvestasi di perusahaan jasa di Indonesia karena saat ini laju pertumbuhan pada sektor ini berfluktuasi. Pada perusahaan jasa terdapat beberapa sub sektor, dimana salah satu satunya adalah sektor pariwisata, hotel, dan restoran.Dengan banyaknya tempat wisata yang menarik di indonesia membuat industri perhotelan dan restoran mengalami perkembangan karena hotel dan restoran selalu dibutuhkan oleh pengunjung yang mendatangi tempat wisata. Tertariknya investor menanamkan modalnya pada industri perhotelan dan restoran tak lepas dari berkembangnya industri pariwisata yang di gencar di promosikan oleh pemerintah dan membuat wisatawan tertarik untuk datang mengunjungi wisata yang ada di Indonesia.

Indonesia memiliki potensi pariwisata tinggi jika dibandingkan dengan negara-negara di Asia Tenggara lainnya, oleh karena itu sektor pariwisata, hotel, dan restoran masih berpeluang diminati oleh investor. Terlebih, di Indonesia sendiri sebenarnya ada banyak infrastruktur sebagai pendorong pembangunan sektor pariwisata seperti hotel dan restoran. Selain dari warisan budaya dan alam serta infrastruktur, faktor lainnya yang dapat mendorong berkembangannya sektor pariwisata adalah ketiadaan 
kriminalitas, ketersediaan dukungan fasilitas kesehatan serta kemudahan memulai bisnis dapat mendorong berkembanganya sektor pariwisata, hotel, dan restoran. pemilik atau para pemegang saham melalui peningkatan nilai perusahaan.Pada umumnya berdirinya suatu perusahaan karena mempunyai suatu tujuan yang ingin dicapai diantaranya memaksimalkan kekayaan pemegang saham sertasekaligus meningkatkan nilai perusahaan.

Kenyataannya saat ini perusahaan-perusahaan yang bergerak di bidang pariwisata, hotel, dan restoran banyak yang mengalami penurunan nilai perusahaan. Penurunan nilai perusahaan tersebut tidak sejalan dengan program pembangunan infrastruktur yang dilakukan oleh pemerintah. Selain itu tingginya tingkat kriminalitas yang terjadi di Indonesia serta dukungan fasilitas kesehatan yang kurang memadai di lokasi-lokasi pariwisata tertentu masih menjadi kendala dalam perkembangan sektor pariwisata, oleh sebab itu perusahaan dan investor berharap pemerintah dapat mengatasi itu semua guna berkembangnya sektor industri pariwisata, hotel, dan restoran.

Selain itu ada beberapa faktor dari dalam perusahaan yang mempengaruhi nilai perusahaan, yaitu: keputusan pendanaan, kebijakan deviden, struktur modal, keputusan investasi, pertumbuhan perusahaan, dan ukuran perusahaan. Beberapa faktor tersebut memiliki hubungan dan pengaruh terhadap nilai perusahaan yang tidak konsisten. Pesatnya perkembangan Bursa Efek Indonesia saat ini tidak bisa dipisahkan dari peran investor atau pemegang saham yang melakukan transaksi di Bursa Efek Indonesia (BEI).

\section{B. Rumusan Masalah}

Berdasarkan latar belakang masalah yang telah diuraikan diatas maka penulis merumuskan permasalahan sebagai berikut:

1. Apakah Struktur Modal berpengaruh terhadap Nilai Perusahaan pada perusahaan sub sektor Pariwisata, Hotel dan Restoran yang terdaftar di BEI tahun 2014-2018?

2. Apakah Likuiditas berpengaruh terhadap Nilai Perusahaan pada perusahaan sub sektor Pariwisata, Hotel dan Restoran yang terdaftar di BEI tahun 2014-2018?

3. Apakah Keputusan Investasi berpengaruh terhadap Nilai Perusahaan pada perusahaan sub sektor Pariwisata, Hotel dan Restoran yang terdaftar di BEI tahun 2014-2018?

4. Apakah Struktur Modal, Likuiditas, dan Keputusan Investasi berpengaruh secara simultan terhadap Nilai Perusahaan pada perusahaan sub sektor Pariwisata, Hotel dan Restoran yang terdaftar di BEI tahun 2014-2018?

\section{Tujuan Penelitian}

Berdasarkan latar belakang dan permasalahan yang telah diuraikan diatas, tujuan penelitian ini adalah :

1. Untuk mengetahui pengaruh Struktur Modal terhadap Nilai Perusahaan pada perusahaan sub sektor Pariwisata, Hotel dan Restoran yang terdaftar di BEI periode 2014-2018.

2. Untuk mengetahui pengaruh Likuiditas terhadap Nilai Perusahaan pada perusahaan sub sektor Pariwisata, Hotel dan Restoran yang terdaftar di BEI periode 2014-2018.

3. Untuk mengetahui pengaruh Keputusan Investasi terhadap Nilai Perusaaan pada perusahaan sub sektor Pariwisata, Hotel dan Restoran yang terdaftar di BEI periode 2014-2018.

4. Untuk mengetahui pengaruh Struktur Modal, Likuiditas, dan 
Keputusan Investasi secara simultan terhadap Nilai Perusaaan pada perusahaan sub sektor Pariwisata, Hotel dan Restoran yang terdaftar di BEI periode 20142018.

\section{LANDASAN TEORI}

\section{A. Signalling Theory}

Menurut Brigham (2011) Signalling Theory adalah suatu tindakan yang diambil manajemen suatu perusahaan yang memberi petunjuk bagi investor tentang bagaimana manajemen memandang prospek perusahaan. Perusahaan dengan prospek yang menguntungkan akan mencoba menghindari penjualan saham dan penggunaan hutang.

Signalling Theory mengemukakan tentang bagaimana seharusnya sebuah perusahaan memberikan sinyal kepada pengguna laporan keuangan. Sinyal ini berupa informasi mengenai apa yang sudah dilakukan oleh manajemen untuk merealisasikan keinginan pemilik. Sinyal dapat berupa promosi atau informasi lain yang menyatakan bahwa perusahaan tersebut lebih baik daripada perusahaan lain.

Dari pengertian diatas dapat disimpulkan bahwa sinyal positif dapat mempengaruhi opini investor dan kreditor atau pihak-pihak lain yang berkepentingan mengenai informasi laporan keuangan yang dapat mencerminkan nilai perusahaan.

\section{B. PengertianManajemen Keuangan}

Menurut Riyanto (2013:4)

Manajemen keuangan adalah

keseluruhan aktivitas yang bersangkutan dengan usaha untuk mendapatkan dana dan menggunakan atau megalokasikan dana tersebut.

Manajemen keuangan adalah suatu proses dalam kegiatan keuangan perusahaan yang berhubungan dengan upaya untuk mendapatkan dana perusahaan dan meminimalkan biaya perusahaan serta upaya pengelolaan keuangan suatu badan usaha atau organisasi untuk mencapai tujuan keuangan yang telah ditetapkan.
Dari pengertian diatas dapat disimpulkan bahwa manajemen keuangan adalah segala aktivitasaktivitas perusahaan yang menyangkut dengan upaya untuk mendapatkan dana, memanfaatkan dana, mengalokasikan dana perusahaan serta meminimalkan biaya untuk dapat menjalankan kegiatan operasional perusahaan dan mencapai tujuan yang telah ditetapkan.

\section{Struktur Modal}

Menurut Harmono (2014) Struktur modal adalah kombinasi atau perimbangan antara utang dan modal sendiri (saham preferen dan saham biasa) yang digunakan perusahaan untuk merencanakan mendapatkan modal.

Menurut Harjito dan Martono (2013) menyatakan bahwa struktur modal adalah perbandingan atau imbangan pendanaan jangka panjang perusahaan yang ditunjukkan oleh perbandingan hutang jangka panjang terhadap modal sendiri.

Dari beberapa pengertian diatas dapat disimpulkan bahwa Struktur modal adalah perbandingan atau perimbangan antara modal asing dengan modal sendiri. Modal asing dalam hal ini disebut utang jangka pendek ataupun jangka panjang dan modal sendiri disebut sebagai laba ditahan atau penyertaan kepemilikan perusahaan.

\section{Likuiditas}

Menurut Irham Fahmi (2013:116) Likuiditas adalah mengukur kemampuan perusahaan dalam memenuhi kewajiban jangka pendeknya. Rasio ini penting karena kegagalan dalam membayar kewajiban dan menyebabkan kebangkrutan perusahaan.

Menurut Kasmir

Likuiditas adalah ketidakmampuan perusahaan membayar kewajibannya terutama utang jangka pendek (yang sudah jatuh tempo disebabkan oleh beberapa faktor. Pertama, bisa dikarenakan memang perusahaan 
sedang tidak memiliki dana sama sekali. Atau kedua, bisa mungkin saja perusahaan memiliki dana, namun saat jatuh tempo perusahaan tidak memiliki dana (tidak cukup) secara tunai sehingga harus menunggu dalam waktu tertentu, untuk mencairkan aktiva lainnya seperti menagih piutang, menjual surat-surat berharga, atau menjual sediaan atau aktiva lainnya.

Dari beberapa pengertian diatas, dapat disimpulkan bahwa likuiditas adalah kemampuan perusahaan dalam membayar atau melunasi kewajiban-kewajibannya terutama utang jangka pendek yang sudah jatuh tempo dengan secara tunai atau mempergunakan aktiva lancarnya yang tersedia.

\section{E. Keputusan Investasi}

Investasi diartikan sebagai penanaman modal perusahaan. Penanaman modal dapat dilakukan pada aktiva riil ataupun aktiva finansiil. Aktiva riil merupakan aktiva yang bersifat fisik atau dapat dilihat jelas secara fisik, misalnya persediaan barang, gedung, tanah dan bangunan. Sedangkan aktiva finansiil merupakan aktiva berupa surat-surat berharga seperti saham dan obligasi. Kemampuan perusahaan mengelola aktiva tersebut sangat menentukan kemampuan perusahaan memperoleh laba yang diinginkan. Pengambilan keputusan yang keliru dalam investasi aktiva tersebut berakibat tersinggungnya pencapaian tujuan perusahaan.

Menurut Tarima et al (2016) Keputusan investasi adalah keputusan yang diambil untuk menanamkan modal pada satu atau lebih aset untuk mendapatkan keuntungan di masa yang akan datang dan permasalahan bagaimana manajer keuangan harus mengalokasikan dana kedalam bentuk-bentuk investasi yang akan dapat mendatangkan keuntungan di masa yang akan datang.

Dari beberapa pengertian diatas, dapat disimpulkan bahwa keputusan investasi adalah keputusan paling penting diantara keputusan yang lain karena keputusan investasi merupakan keputusan jangka panjang yang diambil untuk menanamkan modal pada satu atau lebih aset dalam bentuk aktiva riil atau aktiva finansiil untuk mendapatkan keuntungan di masa yang akan datang.

\section{F. Nilai Perusahaan}

Nilai perusahaan merupakan gambaran keadaan sebuah perusahaan, dimana terdapat penilaian khusus oleh calon investor terhadap baik buruknya kinerja keuangan perusahaan (Mardiyati et al, 2015)

Nilai perusahaan merupakan nilai gabungan dari nilai pasar dari saham yang diterbitkan dan nilai pasar hutang dari suatu perusahaan (Tarima et al, 2016).

Dari beberapa pendapat mengenai nilai perusahaan diatas, maka dapat disimpulkan bahwa nilai perusahaan adalah nilai gabungan dari nilai pasar saham dan nilai pasar hutang yang menggambarkan kondisi perusahaan untuk calon investor menilai bagaimana baik buruknya kinerja keuangan perusahaan.

\section{G. Penelitian Terdahulu}

Penelitian ini mengacu pada penelitian yang pernah dilakukan oleh peneliti sebelumnya. Berikut ini merupakan hasil-hasil penelitian terdahulu yang digunakan sebagai acuan referensi:

Sari dan Wijayanto (2015), Pengaruh Keputusan Investasi, Keputusan Pendanaan dan Kebijakan Dividen terhadap Nilai Perusahaan yang 
terdaftar di Bursa Efek Indonesia Tahun 2011-2013.

Putra dan Lestari (2016), Pengaruh Kebijakan Dividen, Likuiditas, Profitabilitas, dan Ukuran Perusahaan terhadap Nilai Perusahaan yang Terdaftar di Bursa Efek Indonesia Tahun 2010-2013.

Ayem dan Nugroho (2016), Pengaruh Profitabilitas, Struktur Modal, Kebijakan Dividen, dan Keputusan Investasi terhadap Nilai Perusahaan yang Terdaftar di Bursa Efek Indonesia Tahun 2010-2014.

Chasanah dan Adhi (2017), Pengaruh Profitabilitas, Struktur Modal, dan Likuiditas terhadap Nilai Perusahaan yang Terdaftar di Bursa Efek Indonesia Tahun 2012-2015.

Ratnasari et al (2017), Pengaruh Keputusan Investasi, Keputusan Pendanaan, Kebijakan Dividen, dan Profitabilitas terhadap Nilai Perusahaan yang Terdaftar di Bursa Efek Indonesia Tahun 2012-2014.

Rahmawati (2019), Pengaruh Ukuran Perusahaan, Profitabilitas, Struktur Modal, dan Keputusan Investasi terhadap Nilai Perusahaa yang Terdaftar di Bursa Efek Indonesia Tahun 2010-2013.

\section{H. Kerangka Konseptual}

Adapun kerangka konseptual yang dapat digambarkan dalam penelitian ini, dapat dilihat pada gambar berikut ini:

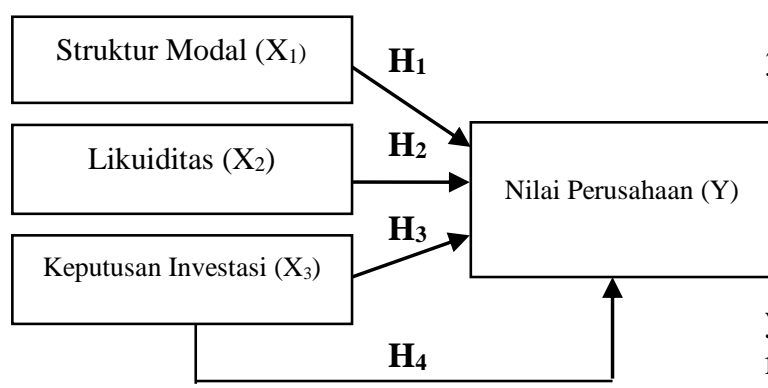

Gambar 2.2

Kerangka Konseptual

\section{Perumusan Hipotesis}

Berdasarkan perumusan maslaah diatas, maka dapat dirumuskan hipotesis penelitian sebagai berikut:

$\mathrm{H}_{1}$ : Struktur Modal berpengaruh terhadap Nilai Perusahaan.

$\mathrm{H}_{2}$ : Likuiditas berpengaruh terhadap Nilai Perusahaan.

$\mathrm{H}_{3}$ : Keputusan Investasi berpengaruh terhadap Nilai Perusahaan.

$\mathrm{H}_{4}$ : Struktur Modal, Likuiditas, dan Keputusan Investasi secara bersama-sama berpengaruh terhadap Nilai Perusahaan

\section{METODE PENELITIAN}

Penelitian ini menggunakan data laporan keuangan tahunan perusahaan jasa yang terdaftar di BEI tahun 2014 sampai dengan 2018.

\section{Populasi dan Sampel Penelitian}

Populasi yang digunakan dalam penelitian ini adalah seluruh perusahaan sub sektor pariwisata, hotel dan restoran yang terdaftar di BEI tahun 2014-2018 yang berjumlah sebanyak 25 perusahaan. Sampel penelitian ditentukan dengan menggunakan metode purposive sampling dengan criteria pemilihan sampel sebagai berikut:

1. Perusahaan Jasa sub sektor Pariwisata, Hotel dan Restoran yang terdaftar di Bursa Efek Indonesia periode tahun 2014-2018.

2. Perusahaan Jasa sub sektor Pariwisata, Hotel dan Restoran yang baru melakukan IPO diatas tahun 2013.

3. Perusahaan Jasa sub sektor Pariwisata, Hotel, dan Restoran yang mengalami kerugian selama periode penelitian 2014-2018.

Dari kriteria diatas jumlah sampel yang memenuhi persyaratan untuk menjadi sampel dalam penelitian ini berjumlah 12 perusahaan sub sektor pariwisat, hotel dan restoran dengan periode 5 tahun yaitu 2014-2018 sehingga data yang diperoleh sebanyak 60 observasi.

\section{Jenis dan Sumber Data}


Data yang digunakan dalam penelitian ini menggunakan data sekunder. Data sekunder adalah data yang diperoleh dalam bentuk sudah jadi atau sudah diolah oleh pihak lain.

Sumber data dalam penelitian ini diperoleh dari laporan keuangan tahunan perusahaan yang telah diaudit dan dipublikasikan dan dapat didownload dari website Bursa Efek Indonesia $w w w . i d x . c o . i d$, Indonesian Capital Market Directory (ICMD), jurnal-jurnal dan sumber lainnya yang terkait dengan penelitian.

\section{Operasional Variabel Penelitian Variabel Dependen}

Variabel dependen dalam penelitian ini adalah Nilai Perusahaan. Nilai Perusahaan merupakan penilaian investor tentang seberapa baik kondisi suatu perusahaan.

Nilai perusahaan menggambarkan kemakmuran pemegang saham dalam jangka panjang sehingga tujuan perusahaan dalam jangka panjang adalah memaksimalkan nilai perusahaan. Maka dapat disimpulkan semakin tinggi harga saham, semakin tinggi pula kemakmuran pemegang saham. Pengukuran Nilai Perusahaan menggunakan rasio PBV. Price to Book Value (PBV) dapat dirumuskan sebagai berikut:

$$
\text { Price to Book Value }=\frac{\text { Harga Saham }}{\text { Nilai Buku }}
$$

\section{Variabel Independen}

\section{Struktur Modal}

Struktur Modal adalah perbandingan atau perimbangan antara modal asing dengan modal sendiri. Modal asing dalam hal ini disebut sebagai utang jangka pendek atau utang jangka panjang dan modal sendiri disebut sebagai laba ditahan atau penyertaan kepemilikan perusahaan. Berikut adalah rumus struktur modal yang diproksikan dengan Debt to Assets Ratio (DAR):

$$
\text { Debt to Asset Ratio }=\frac{\text { Total Debt }}{\text { Total Asset }}
$$

\section{Likuiditas}

Likuiditas adalah kemampuan perusahaan dalam membayar atau melunasi kewajiban-kewajibannya terutama utang jangka pendek yang sudah jatuh tempo dengan cara tunai atau mempergunakan aktiva lancarnya yang tersedia. Berikut adalah rumus likuiditas yang diproksikan dengan Current Ratio (CR):

$$
\mathrm{CR}=\frac{\text { Current Assets }}{\text { Current Liabilities }} \times 100 \%
$$

\section{Keputusan Investasi}

Keputusan investasi adalah keputusan paling penting diantara keputusan yang lain karena keputusan investasi merupakan keputusan jangka panjang yang diambil untuk menanamkan modal pada satu atau lebih aset dalam betuk aktiva riil atau aktiva finansiil untuk mendapatkan keuntungan di masa yang akan datang. Berikut ini adalah rumus keputusan investasi yang diproksikan dengan Price Earning Ratio (PER):

$$
\text { PER }=\frac{\text { Harga penutupan saham }}{\text { Earning Per Share }}
$$

\section{HASIL DAN PEMBAHASAN Statistik Deskriptif}

Tabel 1

Hasil Analisis Statistik Deskriptif

\begin{tabular}{|l|c|c|c|c|}
\hline & PBV & DAR & CR & PER \\
\hline Mean & 2.270167 & 0.399833 & 1.551167 & 182.9435 \\
\hline Median & 1.185000 & 0.425000 & 1.440000 & 24.35000 \\
\hline Maximum & 13.97000 & 0.660000 & 3.740000 & 2810.460 \\
\hline Minimum & 0.190000 & 0.120000 & 0.720000 & 3.460000 \\
\hline Std. Dev. & 2.933634 & 0.128294 & 0.681837 & 488.0237 \\
\hline Observations & 60 & 60 & 60 & 60 \\
\hline
\end{tabular}

Sumber: Output Eviews 9.0 
Berdasarkan hasil output pengujian statistik deskriptif menunjukkan bahwa jumlah data (observations) yang digunakan dalam penelitian ini sebanyak 60 data. Penjelasan untuk deskripsi masing-masing variabel dalam penelitian ini ialah sebagai berikut:

a. Variabel (Y) yaitu Nilai Perusahaan memiliki nilai rata-rata (mean) selama periode 2014-2018 sebesar 2.270167. Nilai maximum PBV sebesar 13.97000 dialami oleh PT. Pioneerindo Gourmet International Tbk pada tahun 2015, sedangkan nilai minimum PBV sebesar 0.190000 yang dimiliki oleh PT. Mas Murni Indonesia Tbk pada tahun 2014 dan nilai standar deviasinya adalah sebesar 2.933634 .

b. Variabel Struktur Modal yang diproksikan dengan DAR memiliki nilai rata-rata (mean) selama periode 2014-2018 sebesar 0.399833. Nilai maximum DAR sebesar 0.660000 dialami oleh PT. Island Concepts Indonesia Tbk pada tahun 2016, sedangkan nilai minimum DAR sebesar 0.120000 dialami oleh PT. Pembangunan Graha Lestari Tbk pada tahun 2015 dan nilai standar deviasinya adalah sebesar 0.128294 .

c. Variabel Likuiditas yang diproksikan dengan CR memiliki nilai rata-rata (mean) selama periode 2014-2018 sebesar 1.551167. Nilai maximum CR sebesar 3.740000 dialami oleh PT. Pembangunan Graha Lestari Tbk pada tahun 2015, sedangkan nilai minimum CR sebesar 0.720000 dialami oleh PT. Indonesian Paradise Property Tbk pada tahun 2017 dan nilai standar deviasinya adalah sebesar 0.681837 .

d. Variabel Keputusan Investasi yang diproksikan dengan PER memiliki nilai rata-rata (mean) selama periode 2014-2018 sebesar 182.9435. Nilai maximum PER sebesar 2810.460 dialami oleh PT. Hotel Sahid Jaya International Tbk pada tahun 2018, sedangkan nilai minimum PER sebesar 3.460000 dialami oleh PT.
Island Concepts Indonesia Tbk pada tahun 2018 dan nilai standar deviasinya adalah sebesar 488.0237.

\section{Uji Hipotesis}

Uji F (Simultan)

Hasil pengujian statistik $F$ ditunjukkan pada tabel berikut ini:

Tabel 2

Hasil Uji F

Sumber: Output Eviews 9.0

\begin{tabular}{|c|c|}
\hline F-statistic & 10.33924 Durbin-Watson stat 1.356655 \\
\hline Prob(F-statistic) & 0.000016 \\
\hline
\end{tabular}

Berdasarkan output diatas menunjukkan bahwa nilai F-statistik sebesar 10.33924 sementara $F$ tabel dengan tingkat $\alpha=5 \%$ df1 (k-1) $=4-1=$ 3 dan df2 $(n-k)=60-4=56$ didapat nilai F Tabel sebesar 2,77. Dengan demikian, F-statistic (10.33924) > F tabel $(2,77)$ dan nilai Prob. (F-statistic) $0.000016<\alpha$ $(0,05)$ yang artinya $\mathrm{H}_{\mathrm{a}}$ diterima. Maka dapat disimpulkan bahwa variabel independen dalam penelitian ini Struktur Modal (DAR), Likuiditas (CR), dan Keputusan Investasi (PER) secara simultan berpengaruh terhadap Nilai Perusahaan (PBV).

\section{Koefisien Determinasi (Adjusted $R$ - squared)}

Tabel 3

Koefisien Determinasi

Sumber: Output Eviews 9.0

Berdasarkan pada tabel 3 diatas menunjukan bahwa nilai Adjusted $R$ squared sebesar 0.321977, artinya bahwa variasi perubahan naik turunnya Nilai Perusahaan (PBV) dapat dijelaskan oleh Struktur Modal (DAR), Likuiditas (CR) dan Keputusan Investasi (PER) sebesar 32,19\% sementara sisanya yaitu $67,81 \%$ dijelaskan oleh variabel - 
variabel lain yang tidak diteliti dalam penelitian ini.

\section{Uji t (Parsial)}

\section{Tabel 4 Hasil Uji t}

Variable Coefficient Std. Error t-Statistic Prob.

\begin{tabular}{ccccc}
\hline \hline & & & & \\
C & -0.879972 & 1.576172 & -0.558297 & 0.5789 \\
DAR & 6.854830 & 2.913375 & 2.352883 & 0.0222 \\
CR & 0.020506 & 0.284683 & 0.072032 & 0.9428 \\
PER & 0.002064 & 0.000467 & 4.419961 & 0.0000 \\
\hline \hline
\end{tabular}

Sumber: Output Eviews 9.0

Berdasarkan tabel 4 hasil uji $\mathrm{t}$ menunjukkan nilai sebagai berikut:

1. Struktur Modal

Nilai $t$-statistic Struktur Modal (DAR) sebesar 2.352883, sementara $\mathrm{t}$ tabel dengan tingkat $\alpha$ $=5 \%$, $\mathrm{df}(\mathrm{n}-\mathrm{k})=56$ didapat nilai $\mathrm{t}$ tabel sebesar 2.00324. Dengan demikian $t$-statistic DAR 2.352883 $>\mathrm{t}$ tabel 2.00324 dan nilai Prob. $0.0222<0,05$. Maka dapat disimpulkan bahwa variabel Struktur Modal (DAR) dalam penelitian ini memiliki pengaruh terhadap Nilai Perusahaan (PBV).

2. Likuiditas

Nilai t-statistic Likuiditas (CR) sebesar 0.072032 , sementara $t$ tabel dengan tingkat $\alpha=5 \%$, df $(\mathrm{n}-\mathrm{k})=$ 56 didapat nilai $\mathrm{t}$ tabel sebesar 2.00324. Dengan demikian $t$ statistic CR $0.072032<\mathrm{t}$ tabel 2.00324 dan nilai Prob. $0.9428>$ 0.05. Maka dapat disimpulkan bahwa variabel Likuiditas (CR) dalam penelitian ini tidak memiliki pengaruh terhadap Nilai Perusahaan (PBV).

3. Keputusan Investasi

Nilai $t$-statistic Keputusan Investasi (PER) sebesar 4.419961, sementara $\mathrm{t}$ tabel dengan tingkat $\alpha=5 \%$, df $(\mathrm{n}-\mathrm{k})=56$ didapat nilai $\mathrm{t}$ tabel sebesar 2.00324. Dengan demikian $t$-statistic PER $4.419961>\mathrm{t}$ tabel 2.00324 dan nilai Prob. $0.0000<$
0.05. Maka dapat disimpulkan bahwa variabel Keputusan Investasi (PER) dalam penelitian ini memiliki pengaruh terhadap Nilai Perusahaan (PBV).

\section{Analisis Regresi Data Panel \\ Tabel 5 \\ Analisi Regresi Data Panel \\ Variable Coefficient Std. Error t-Statistic Prob.

\begin{tabular}{lllll} 
C & -0.879972 & 1.576172 & -0.558297 & 0.5789 \\
DAR & 6.854830 & 2.913375 & 2.352883 & 0.0222 \\
CR & 0.020506 & 0.284683 & 0.072032 & 0.9428 \\
PER & 0.002064 & 0.000467 & 4.419961 & 0.0000 \\
\hline
\end{tabular}

Sumber: Output Eviews 9.0

$\mathrm{Y}=-0.879972+6.854830 \mathrm{DAR}+0.020506 \mathrm{CR}+0.002064 \mathrm{PER}+\varepsilon$

Dari persamaan diatas dapat dijelaskan bahwa:

a. Konstanta $(\alpha)$ sebesar -0.879972 menunjukan bahwa jika variabel Independen (DAR, CR dan PER) pada observasi ke $\mathrm{i}$ dan periode ke $\mathrm{t}$ adalah 0, maka nilai perusahaan 0.879972 .

b. Nilai koefisien regresi DAR $\left(\mathrm{X}_{1}\right)$ sebesar 6.854830 menunjukan bahwa jika DAR pada observasi ke i dan periode ke $\mathrm{t}$ naik sebesar 1\% dengan asumsi variabel lainnya tetap, maka akan menaikan nilai perusahaan pada observasi ke i dan periode ke $\mathrm{t}$ sebesar 6.854830

c. Nilai koefisien regresi CR $\left(\mathrm{X}_{2}\right)$ sebesar 0.020506 menunjukan bahwa jika CR pada observasi ke i dan periode ke $\mathrm{t}$ naik sebesar $1 \%$ dengan asumsi variabel lainnya tetap, maka akan menaikan nilai perusahaan pada observasi ke $\mathrm{i}$ dan periode ke $\mathrm{t}$ sebesar 0.020506 .

d. Nilai koefisien regresi PER $\left(\mathrm{X}_{3}\right)$ sebesar 0.002064 menunjukan bahwa jika PER pada observasi ke i dan periode ke $\mathrm{t}$ naik sebesar $1 \%$ dengan asumsi variabel lainnya tetap, maka akan menaikan nilai 
perusahaan pada observasi ke i dan periode ke t sebesar 0.002064 .

\section{Interpretasi Hasil}

\section{a. Pengaruh Struktur Modal terhadap Nilai Perusahaan}

Struktur modal merupakan kunci perbaikan produktivitas dan kinerja perusahaan, karena struktur modal berkaitan dengan pendanaan untuk kegiatan operasional maupun investasi perusahaan yang berasal dari ekuitas (modal sendiri) dan hutang.

Pada hipotesis pertama $\left(\mathrm{H}_{2}\right)$ menyatakan bahwa nilai $t$-statistic DAR sebesar 2.352883, sementara t tabel dengan tingkat $\alpha=5 \%$, df (n$\mathrm{k})=56$ didapat nilai $\mathrm{t}$ tabel sebesar 2.00324, dengan demikian $t$ statistic DAR (2.352883) $>\mathrm{t}$ tabel (2.00324) dan nilai Prob. $0.0222<$ 0,05. Maka dapat disimpulkan $\mathrm{H}_{\mathrm{a}}$ diterima. Dengan demikian, variabel Struktur Modal yang diproksikan dengan Debt to Assets Ratio (DAR) secara parsial dalam penelitian ini berpengaruh signifikan terhadap Nilai Perusahaan yang diproksikan oleh Price to Book Value (PBV). Struktur modal dapat mempengaruhi kondisi keuangan perusahaan. Struktur modal dikatakan optimal apabila perusahaan dapat mengimbangi antara risiko dan return. selain itu struktur modal yang optimal dapat mempengaruhi kelangsungan hidup perusahaan dan dapat memprediksi risiko bisnis sehingga struktur modal perusahaan bisa menjadi sinyal positif bagi investor dalam berinvestasi sehingga dapat meningkatkan nilai perusahaan.

Hasil penelitian ini sejalan dengan hasil penelitian terdahulu yang dilakukan oleh Chasanah dan Adhi (2017) yang menyatakan bahwa struktur modal berpengaruh positif terhadap nilai perusahaan. Namun penelitian ini tidak sejalan dengan penelitian yang dilakukan
Ayem dan Nugroho (2016) yang menyatakan bahwa struktur modal tidak berpengaruh terhadap nilai perusahaan.

b. Pengaruh Likuiditas terhadap Nilai Perusahaan

Pada hipotesis kedua $\left(\mathrm{H}_{2}\right)$ menyatakan bahwa nilai $t$-statistic Likuiditas (CR) sebesar 0.072032, sementara $\mathrm{t}$ tabel dengan tingkat $\alpha$ $=5 \%$, df $(\mathrm{n}-\mathrm{k})=56$ didapat nilai $\mathrm{t}$ tabel sebesar 2.00324. Dengan demikian $t$-statistic CR $0.072032<$ $\mathrm{t}$ tabel 2.00324 dan nilai Prob. $0.9428>0.05$. Maka dapat disimpulkan $\mathrm{H}_{0}$ diterima. Dengan demikian, variabel Likuiditas yang diproksikan denga Current Ratio (CR) dalam penelitian ini tidak memiliki pengaruh terhadap Nilai Perusahaan yang diproksikan dengan Price to Book Value (PBV).

Berdasarkan penelitian yang telah dilakukan, $\mathrm{H}_{3}$ ditolak yang artinya likuiditas tidak berpengaruh terhadap nilai perusahaan. Semakin tinggi tingkat likuiditas maka nilai perusahaan akan semakin menurun. Informasi tentang likuiditas direspon dan dipertimbangkan oleh investor maupun pihak eksternal dalam menilai kinerja keuangan suatu peusahaan. Current ratio yang rendah dapat berdampak pada penurunan harga saham perusahaan yang menyebabkan menurunnya nilai perusahaan namun jika terlalu tinggi dapat mengurangi kemampuan laba perusahaan karena banyaknya dana menganggur. Adanya piutang tak tertagih dan persediaan yang belum dijual dapat menyebabkan tingginya current ratio. Jika hal tersebut lebih mendominasi komponen aktiva lancar lainnya tentunya ini berdampak pada current ratio perusahaan akan tinggi dan seolaholah perusahaan berada dalam kondisi yang likuid, sehingga investor akan melihat itu sebagai sinyal negatif. 
Selain itu, likuiditas yang terlalu tinggi adalah hal yang tidak produktif bagi perusahaan. Likuiditas yang berlebihan berisiko terjadi penyelewengan atau penyimpangan penggunaan dana oleh manajer perusahaan. Perusahaan yang mempunyai likuiditas yang sangat tinggi berisiko memliki masalah keagenan dalam perusahaan. Masalah keagenan tersebut memberikan sinyal negatif kepada investor dan dapat menurunkan nilai perusahaan. Likuiditas yang tinggi atau jumlah aktiva likuid dalam neraca terlalu besar dapat dikarenakan oleh sulitnya perusahaan dalam mencari sumber pendanaan eksternal. Hal itu merupakan sinyal negatif yang ditimbulkan yang dapat menurunkan nilai perusahaan. Informasi tersebut memberikan sinyal kepada investor. Penelitian ini sejalan dengan Signalling Theory. Menurut Brigham (2011) Signalling Theory adalah suatu tindakan yang diambil manajemen suatu perusahaan yang memberi petunjuk bagi investor tentang bagaimana manajemen memandang prospek perusahaan.

Likuiditas yang terlalu tinggi atau berada diatas titik optimal dapat menurunkan nilai perusahaan, karena adanya aset menganggur yang tidak dimanfaatkan oleh perusahaan dalam operasionalnya. Kemudian, investor dalam menentukan investasi tidak memperhatikan faktor likuiditas yang dimiliki perusahaan terlebih rasio ini hanya menunjukkan kemampuan perusahaan dalam memenuhi kewajiban jangka pendeknya sehingga likuiditas tidak berpengaruh dalam pertumbuhan nilai perusahaan.

Hasil penelitian ini sejalan dengan hasil penelitian terdahulu yang dilakukan oleh Lumoly et al (2018) yang menyatakan bahwa likuiditas tidak berpengaruh terhadap nilai perusahaan. Namun penelitian ini tidak sejalan dengan penelitian yang dilakukan Putra dan Lestari (2016) yang menyatakan bahwa likuiditas berpengaruh terhadap nilai perusahaan.

c. Pengaruh Keputusan Investasi terhadap Nilai Perusahaan

Pada hipotesis keempat $\left(\mathrm{H}_{4}\right)$ menyatakan bahwa nilai $t$-statistic Keputusan Investasi (PER) sebesar 4.419961, sementara t tabel dengan tingkat $\alpha=5 \%$, df $(\mathrm{n}-\mathrm{k})=56$ didapat nilai $t$ tabel sebesar 2.00324. Dengan demikian $t$ statistic PER $4.419961>\mathrm{t}$ tabel 2.00324 dan nilai Prob. $0.0000<$ 0.05. Maka dapat disimpulkan $\mathrm{H}_{\mathrm{a}}$ diterima. Dengan demikian, variabel Keputusan Investasi yang diproksikan dengan Price Earning Ratio (PER) dalam penelitian ini memiliki pengaruh terhadap Nilai Perusahaan yang diproksikan dengan Price to Book Value (PBV).

Berdasarkan penelitian yang telah dilakukan, $\mathrm{H}_{4}$ diterima yang artinya keputusan investasi berpengaruh positif terhadap nilai perusahaan. Hal ini menandakan bahwa semakin besar keputusan investasi yang dikeluarkan oleh perusahaan akan berdampak pada peningkatan nilai perusahaan. Apabila perusahaan memiliki peluang investasi yang besar, maka perusahaan memerlukan tambahan dana untuk mendanai peluang investasi yang akan dipilih sehingga dapat menaikkan harga saham dan meningkatkan nilai perusahaan. Dengan peningkatan nilai PER mengindikasikan bahwa keadaan perusahaan dalam keadaan sehat dan mengalami pertumbuhan. Keputusan yang dilakukan perusahaan dalam bentuk investasi aktiva yang tinggi dianggap investor sebagai informasi yang baik, dengan adanya investasi yang tinggi dari perusahaan maka keuntungan dimasa yang akan datang akan tinggi pula sehingga 
berdampak pada peningkatan nilai perusahaan.

Keputusan investasi memberikan pengaruh positif terhadap nilai perusahaan yang dibentuk melalui indikator nilai pasar saham yang dipengaruhi oleh peluang investasi. Pengaruh ini dapat dipengaruhi melalui pemilihan proyek atau kebijakan lainnya seperti menciptakan produk baru dan membeli aset untuk mengefisiensikan kegiatan operasionalnya untuk menghasilkan keuntungan dimasa yang akan datang.

Informasi keputusan investasi yang tinggi memberikan sinyal positif kepada investor tentang nilai perusahaan. Penelitian ini sejalan dengan signalling theory. Pelaporan informasi keuangan tentang keputusan investasi dan nilai perusahaan kepada investor melalui proksi PER dan PBV menandakan bahwa semua pihak mampu menerima informasi yang sama.

Hasil penelitian ini sejalan dengan penelitian yang dilakukan oleh Ayem dan Nugroho (2016), Ratnasari et al (2017) menyatakan bahwa keputusan investasi berpengaruh positif signifikan terhadap nilai perusahaan.

a. Pengaruh Struktur Modal, Likuiditas, dan Keputusan Investasi secara simultan terhadap Nilai Perusahaan

Berdasarkan hasil olah data statistik dapat dilihat bahwa Struktur Modal, Likuiditas dan Keputusan Investasi secara simultan berpengaruh signifikan terhadap Nilai Perusahaan pada perusahaan jasa sub sektor pariwisata, hotel dan restoran yang terdaftar di BEI tahun 2014-2018. Hal ini dibuktikan dengan hasil Uji $F$ yang menunjukkan nilai $F-$ statistic sebesar 10.33924, sementara $F$ Tabel dengan tingkatan $\alpha=5 \%$, dfl (k-1) = 3 dan df2 $(\mathrm{n}-\mathrm{k})=56$ didapat nilai $\mathrm{F}$ Tabel sebesar 2,77. Dengan demikian $F$ statistic (10.33924) > F Tabel $(2,77)$ dan nilai Prob. (F-statistic) $0.000016<0,05$.

Berdasarkan penelitian yang telah dilakukan, $\mathrm{H}_{1}$ diterima yang artinya struktur modal, likuiditas, dan keputusan investasi berpengaruh secara simultan terhadap nilai perusahaan. Struktur Modal mempunyai peranan yang cukup penting dalam nilai perusahaan karena rasio tersebut mengatur kebutuhan perusahaan, antara memaksimalkan return (meminimalkan biaya modal). Struktur modal menunjukkan perbandingan antara modal eksternal jangka panjang dengan modal sendiri, hal ini merupakan aspek yang penting bagi setiap perusahaan karena mempunyai efek langsung terhadap posisi finansial perusahaan.

Likuiditas juga memiliki peran yang baik dalam mempengaruhi nilai perusahaan karena likuiditas merupakan kemampuan perusahaan dalam memenuhi kewajiban jangka pendek yang sudah jatuh tempo. Apabila perusahaan memiliki tingkat likuiditas yang rendah maka perusahaan akan kehilangan kepercayaan investor yang melihat rendahnya kemampuan perusahaan dalam memenuhi jangka pendeknya, hal tersebut dapat membuat harga saham menurun dan bepengaruh terhadap nilai perusahaan.

Selain itu, keputusan investasi juga memiliki peran yang penting dalam nilai perusahaan. Karena kegiatan investasi yang dilakukan oleh perusahaan adalah untuk memperoleh keuntungan dimasa yang akan datang yaitu dapat menarik investor untuk menanamkan modalnya sehingga dapat meningkatkan nilai perusahaan. 


\section{KESIMPULAN}

Penilitian ini bertujuan untuk mengetahui pengaruh Struktur Modal, Likuiditas, dan Keputusan Investasi terhadap Nilai Perusahaan pada perusahaan jasa sub sektor pariwisata, hotel dan restoran yang terdaftar di Bursa Efek Indonesia periode 20142018. Berdasarkan pendahuluan, kajian teori, dan pengolahan data serta pembahasan yang telah dilakukan pada bab terdahulu, maka dapat disimpulkan sebagai berikut:

1. Hasil penelitian menunjukkan Struktur Modal yang diproksikan dengan Debt to Assets Ratio (DAR) secara parsial berpengaruh terhadap nilai perusahaan pada perusahaan jasa sub sektor pariwisata, hotel dan restoran periode 2014-2018. Hal ini dibuktikan dengan menggunakan uji t yang menghasilkan nilai $t_{\text {statistik }}$ sebesar $2.352883>\mathrm{t}_{\text {tabel }}$ sebesar 2.00324 dengan nilai signifikansi sebesar $0.0222<0.05$, maka $\mathrm{H}_{1}$ diterima.

2. Hasil penelitian menunjukkan Likuiditas yang diproksikan dengan Current Ratio (CR) secara parsial tidak berpengaruh terhadap nilai perusahaan pada perusahaan jasa sub sektor pariwisata, hotel dan restoran periode 2014-2018. Hal ini dibuktikan dengan menggunakan uji t yang menghasilkan nilai $t_{\text {statistik }}$ sebesar $0.072032<\mathrm{t}_{\text {tabel }}$ sebesar 2.00324 dengan nilai signifikansi sebesar $0.9428>0.05$, maka $\mathrm{H}_{2}$ tidak terbukti (ditolak).

3. Hasil penelitian menunjukkan Keputusan Investasi yang diproksikan dengan Price Earning Ratio (PER) secara parsial berpengaruh terhadap nilai perusahaan pada perusahaan jasa sub sektor pariwisata, hotel dan restoran periode 2014-2018. Hal ini dibuktikan dengan menggunakan uji $\mathrm{t}$ yang menghasilkan nilai $\mathrm{t}_{\text {statistik }}$ sebesar $4.419961>t_{\text {tabel }}$ sebesar 2.00324 dengan nilai signifikansi sebesar $0.0000<0.05$, maka $\mathrm{H}_{3}$ diterima.
4. Hasil penelitian menunjukkan Struktur Modal, Likuiditas, dan Keputusan Investasi secara simultan berpengaruh terhadap nilai perusahaan pada perusahaan jasa sub sektor pariwisat, hotel dan restoran periode 2014-2018. Hal ini dibuktikan dengan menggunakan uji $\mathrm{F}$ yang menghasilkan $\mathrm{F}_{\text {statistik }}$ sebesar $10.33924>$ nilai $F_{\text {tabel }}$ sebesar 2.77 dengan nilai probabilitas $\mathrm{F}_{\text {statistik }} 0.000016$ < 0.05 , maka $\mathrm{H}_{4}$ diterima.

\section{Keterbatasan}

Penelitian ini menjelaskan keterbatasan yang dialami sebagai konsekuensi logis dari kesimpulan penelitian ini dan ditindaklanjuti dengan upaya perbaikan. Keterbatasan penelitian ini secara ringkas dan jelas adalah sebagai berikut:

1. Sampel yang digunakan dalam penelitian adalah 12 perusahaan yang tercatat di Bursa Efek Indonesia periode 2014-2018.

2. Variabel yang digunakan dalam penelitian ini berjumlah 3 variabel independen yang kemungkinan pengaruhnya terhadap nilai perusahaan kecil karena masih banyak variabel yang dapat menjelaskan pengaruh terhadap nilai perusahaan yang tidak terdapat dalam penelitian ini.

3. Variabel yang digunakan dalam penilitian ini masih terbatas, hal ini terlihat dari nilai koefisien determinasi (Adjusted R-squared) yang mempengaruhi nilai perusahaan tidak mencapai $50 \%$ yaitu hanya sebesar 0.321977 atau sekitar $32 \%$.

\section{Rekomendasi}

Beberapa rekomendasi yang dapat penulis berikan sehubungan dengan penelitian ini adalah sebagai berikut:

1. Saran Teoritis

a. Bagi Mahasiswa

Agar penelitian ini dapat dimanfaatkan sebagai bahan referensi penelitian selanjutnya dan sebagai perbandingan untuk 
menambah ilmu pengetahuan di bidang manajemen dan akuntansi.

b. Bagi Penulis

Sebagai sarana untuk memperluas wawasan serta menambah referensi mengenai manajemen keuangan terutama tentang kinerja keuangan sehingga dapat dimanfaatkan bagi penulis di masa yang akan datang.

c. Bagi Peneliti

Bagi peneliti selanjutnya yang ingin melakukan penelitian sejenis, sebaiknya menggunakan variabel atau proksi lain yang tidak digunakan dalam penelitian ini serta menambah jumlah sampel dengan menambah sektor lain yang terdaftar di BEI. Selain itu sebaiknya memperpanjang periode penelitian, sehingga dapat memberikan hasil penelitian yang lebih bervariasi dan lebih maksimal terhadap pengaruh nilai perusahaan.

2. Saran Praktis

a. Bagi Perusahaan

Diharapkan sebaiknya lebih memperhatikan kelengkapan data perusahaan, karena hal tersebut merupakan kewajiban bagi perusahaan publik untuk mempublikasikan ke masyarakat sebagai pengguna laporna keuangan. Sehingga untuk penelitian selanjutnya dapat dengan mudah mengakses dan memperoleh data. Selain itu, perusahaan juga harus memperhatikan nilai perusahaan dengan baik karena nilai perusahaan merupakan salah satu indikator penilaian yang digunakan oleh calon investor sebelum menanamkan modalnya pada suatu perusahaan.

b. Bagi Investor dan Calon Investor Investor harus dapat mempertimbangkan manakah perusahaan yang memiliki struktur modal, likuiditas dan keputusan investasi yang baik sebelum memutuskan untuk menanamkan modalnya. Hal tersebut dikarenakan apabila perusahaan memiliki kondisi keuangan yang baik, memiliki kemampuan dalam memenuhi kewajiban jangka pendeknya dan pertumbuhan investasi yang baik dapat memberikan pengaruh yang baik bagi nilai perusahaan dan kemungkinan return yang akan didapatkan investor pun juga akan besar.

\section{DAFTAR PUSTAKA}

Achmad, Safitri Lia dan Lailatul Amanah. 2014. Pengaruh Keputusan Investasi, Keputusan Pendanaan, Kebijakan Dividen, dan Kinerja Keuangan terhadap Nilai Perusahaan. Jurnal Ilmu \& Riset Akuntansi, Vol. 3 No. 9: 1-15

Ananta, Gede Eka Ferry et al. 2014. Pengaruh Kepemilikan Manajerial, Keputusan Investasi, Keputusan Pendanaan dan Kebijakan Dividen terhadap Nilai Perusahaan di BEI. E-Jurnal Ekonomi dan Bisnis Universitas Udayana, Vol. 9 No. 3: 495-505

Awulle, Irma Desmi et al. 2018. Pengaruh Profitabilitas, Likuiditas, Solvabilitas, dan Kepemilikan Institusional Terhadap Nilai Perusahaan Pada Perusahaan Food And Beverage Yang Terdaftar di BEI Periode 2012-2016. Universitas Sam Ratulangi Manado. Jurnal EMBA, Vol. 6 No. 4: 1908-1917

Ayem, Sri dan Ragil Nugroho. 2016. Pengaruh Profitabilitas, Struktur Modal, Kebijakan Dividen, Dan Keputusan Investasi Terhadap Nilai 
Perusahaan (Studi Kasus Perusahaan Manufaktur Yang Go Publik Di Bursa Efek Indonesia Tahun 20102014). Jurnal Akuntansi, Vol. 4 No.1 : 31-39

Basuki, Agus Tri dan Nano Prawoto. 2016. Analisis Regresi Dalam Penelitian Ekonomi dan Bisnis : Dilengkapi Aplikasi SPSS dan EVIEWS. Jakarta: RajaGrafindo Persada.

Chasanah, AN dan Daniel KA. 2017. Pengaruh Profitabilitas, Struktur Modal dan Likuiditas Terhadap Nilai Perusahaan Pada Perusahaan Real Estate Yang Listed di BEI Tahun 2012-2015. Fokus Ekonomi, Vol. 12 No. 2: 131-146

Fahmi, Irham. 2013. Analisis Laporan Keuangan. Bandung: Alfabeta

Fahmi, Irham. 2014. Pengantar Manejemen Keuangan. Bandung: Alfabeta

$\begin{array}{cc}\text { Manejemen } & \text { 2015. Pengantar } \\ \text { Bandung: Alfabeta }\end{array}$

Faridah Nur dan Kurnia. 2016. Pengaruh Keputusan Investasi, Keputusan Pendanaan, Kebijakan Dividen dan Tingkat Suku Bunga terhadap Nilai Perusahaan. Jurnal Ilmu dan Riset Akuntansi. Vol. 5 No. 2: $1-15$

Ghozali, Imam dan Dwi Ratmono. 2016. Analisis Multivariat dan Ekonometrika Teori, Konsep, dan Aplikasi dengan Eviews8. Semarang: Badan Penerbit Universitas Diponegoro.

Gujarati dan Porter. 2009. Dasar-Dasar Ekonometrika. Jakarta: Salemba Empat

Hanafi, MM. 2016. Manajemen Keuangan. Yogyakarta: BPFE.
Harjito, Agus dan Martono. 2013. Manajemen Keuangan. Edisi ke-2. Yogyakarta: Ekonisia.

Harmono. 2011. Manajemen Keuangan Berbasis Balanced Scorecard Pendekatan Teori, Kasus, dan Riset Bisnis. Edisi ke-1. Jakarta: Bumi Aksara 2014. Manajemen Keuangan Berbasis Balanced Scorecard Pendekatan Teori, Kasus, dan Riset Bisnis. Jakarta: Bumi Aksara

Husnan, Suad dan Enny Pudjiastuti. 2015. Dasar-Dasar Manajemen Keuangan. Edisi ke-7. Yogyakarta: UPP STIM YKPN

Ilhamsyah, Fendyka Luqman dan Hendri Soekotjo. 2017. Pengaruh Kebijakan Dividen, Keputusan Investasi, dan Profitabilitas terhadap Nilai Perusahaan. Jurnal Ilmu dan Riset Manajemen, Vol. 6 No. 2: 115

Jayanti, Agnes Cintia. 2018. Pengaruh Profitabilitas, Keputusan Investasi, Keputusan Pendanaan Dan Kebijakan Dividen Terhadap Nilai Perusahaan. Universitas Negeri Jakarta: Skripsi

Kasmir. 2014. Analisis Laporan Keuangan. Edisi ke-1. Jakarta: Rajawali Pers

2018. Analisis Laporan Keuangan. Depok: RajaGrafindo Persada

Lumoly, Selin et al. 2018. Pengaruh Likuiditas, Ukuran Perusahaan, dan Profitabilitas Terhadap Nilai Perusahaan (Studi Pada Perusahaan Logam dan Sejenisnya yang Terdaftar di BEI 2013-2017). Universitas Sam Ratulangi Manado. Jurnal EMBA, Vol. 6 No. 3: 1108-1117

Lusiana, Dewi dan Dewi Agustina. 2015. Faktor-faktor Yang 
Mempengaruhi Nilai

Perusahaan Pada

Perusahaan Non Keuangan.

E-Jurnal Manajemen Unud,

Vol. 4 No. 12: 81-91

Mardiyati, Umi et al. 2015. Pengaruh Keputusan Investasi,

Keputusan Pendanaan,

Ukuran Perusahaan dan

Profitabilitas terhadap Nilai

Perusahaan pada Sektor

Manufaktur Barang

Konsumsi yang Terdaftar di BEI periode 2010-2013.

Jurnal Riset Manajemen

Sains Indonesia (JRMSI),

Vol. 6 No. 1: 1-23

Mulyawan, Setia. 2015. Manajemen Keuangan. Bandung: CV. Pustika Setia

Putra, AA Ngurah Dharma Adi dan Putu Vivi Lestari. 2016. Pengaruh Kebijakan Dividen, Likuiditas, Profitabilitas dan Ukuran Perusahaan terhadap Nilai Perusahaan. E-Journal Manajemen Unud, Vol. 5 No. 7: 4044-4070

Ratnasari, Siti et al. 2017. Pengaruh Keputusan Investasi, Keputusan Pendanaan, Kebijakan Dividen, dan Profitabilitas Terhadap Nilai Perusahaan Pada Perusahaan Manufaktur Sektor Industri Barang Konsumsi Yang Terdaftar di BEI 2012-2014. STIE YPPI Rembang. Buletin Bisnis \& Manajemen, Vol. 03 No. 01

Riadi, Muchlisin. 2017. Pengertian, Jenis dan Pengukuran Nilai Perusahaan. Diambil dari: www.kajianpustaka.com/20 17/11/pengertian-jenis-danpengukuran-nilai-

perusahaan.html (10 Mei 2019).

Sari, EL dan Adhi Wijayanto. 2015. Pengaruh Keputusan Investasi, Pendanaan, dan Dividen Terhadap Nilai
Perusahaan Dengan Risiko Sebagai Variabel Mediasi. Management Analysis Journal, Vol. 4 No. 4: 281291

Sartono, R. Agus. 2014. Manajemen Keuangan Teori dan Aplikasi. Edisi ke-4. Yogyakarta: BFPE UGM

Suroto. 2015. Pengaruh Keputusan Investasi, Keputusan Pendanaan, dan Kebijakan Dividen terhadap Nilai Perusahaan (Studi Empiris pada Perusahaan LQ45 yang Terdaftar di BEI periode 2010-2015). Jurnal Ilmiah UNTAG Semarang, Vol. 4 No. 3: 1-18

Suryani dan Hendryadi. 2015. Metode Riset Kuantitatif: Teori dan Aplikasi Pada Penelitian Bidang Manajemen dan Ekonomi Islam. Edisi ke-1. Jakarta: PRENADAMEDIA GROUP

Tarima, Grandi et al. 2016. Pengaruh Profitabilitas, Keputusan Investasi dan Keputusan Pendanaan terhadap Nilai Perusahaan pada Perusahaan Farmasi yang Terdaftar di BEI $P_{\text {}}$ 2011-2014. Jurnal Berkala Ilmiah Efisiensi, Vol. 16 No. 04: 1-10

Universitas Muhammadiyah Tangerang. 2018. Pedoman Penulisan Skripsi. Tangerang

https://www.jurnal.id/id/blog/2018penjelasan-lengkap-6-teoristruktur-modal/

http://www.idx.co.id Diakses (16 Maret 2019)

http://www.bps.co.id Diakses (25 Maret 2019)

http://www.kemenpar.go.id Diakses (25 Maret 2019) 